\title{
Survey of Kudoa spp. (Myxozoa, Cnidaria) in fishes from the Madeira Archipelago and the Portuguese mainland coast: detection of Kudoa thyrsites in new hosts Scomber colias and Micromesistius poutassou
}

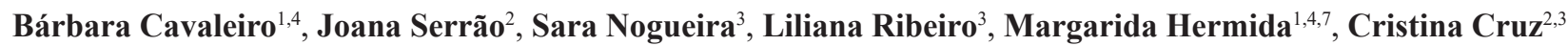 \\ Martina Lisnerová ${ }^{5,6}$, Ivan Fiala ${ }^{5,6}$ and Aurélia Saraiva ${ }^{2,3}$ \\ ${ }^{1}$ MARE, Marine and Environmental Sciences Centre, Agência Regional para o Desenvolvimento da Investigação Tecnologia e \\ Inovação, Funchal, Madeira, Portugal; \\ ${ }^{2}$ CIIMAR, Interdisciplinary Centre of Marine and Environmental Research, Porto, Portugal; \\ ${ }^{3}$ University of Porto, Faculty of Sciences, Biology Department, Porto, Portugal; \\ ${ }^{4}$ Oceanic Observatory of Madeira, Agência Regional para o Desenvolvimento da Investigação Tecnologia e Inovação, Funchal, \\ Madeira, Portugal; \\ ${ }^{5}$ Institute of Parasitology, Biology Centre, Academy of Sciences of the Czech Republic, České Budějovice, Czech Republic; \\ ${ }^{6}$ Faculty of Science, University of South Bohemia, České Budějovice, Czech Republic; \\ ${ }^{7}$ University of Bristol, Department of Philosophy, Bristol, United Kingdom
}

\begin{abstract}
Myxozoan parasites of the genus Kudoa Meglitsch, 1947 are associated with post-mortem tissue degradation that causes great financial losses to commercial fisheries. Kudoa thyrsites (Gilchrist, 1924) is a species with a very wide host range including commercial tunas, mackerels, salmonids and flatfishes. A sample of 190 fishes of 18 species from the Madeira Archipelago and 30 Atlantic chub mackerel, Scomber colias Gmelin, and 30 blue whiting, Micromesistius poutassou (Risso), from the Portuguese mainland coast were examined for the presence of species of Kudoa. The prevalence of Kudoa spp. was $80 \%$ in M. poutassou and $60 \%$ in S. colias. No spore was detected in $S$. colias from Madeira, which was confirmed by specific PCR screening of the muscle from all individuals of $S$. colias. SSU rDNA analysis revealed that $M$. poutassou and S. colias from the Portuguese mainland coast were infected with $K$. thyrsites, an economically important myxozoan parasite. Both sequences were identical with sequences of the eastern Atlantic K. thyrsites genotype, including that from the type host of this parasite. This is the first report of K. thyrsites from M. poutassou and $S$. colias. The fact that spores of species of Kudoa were not detected in fishes screened in the Madeira Archipelago may be explained by various ecological factors, such as the absence of a continental shelf, a short insular shelf, and oceanic waters with low productivity, all resulting in reduced abundance of benthic organisms. Consequently, it is possible that as yet unknown annelid definitive hosts of Kudoa spp. are absent or very rare near Madeiran coasts.
\end{abstract}

Keywords: Atlantic, food safety, parasites, Portugal, scombrid, tuna, Atlantic chub mackerel, blue whiting.

The study of fish parasites has grown over the last decades mainly due to their economic implications in fisheries, aquaculture and, in some cases, risk to human health. Fish parasites that occur in edible parts of the fish are the most relevant for human health. Multivalvulida (Cnidaria: Myxozoa) are widespread and can be associated with mortality or poor flesh quality of commercially important marine fishes (Whipps and Diggles 2006, Kristmundsson and Freeman 2014, Kasai et al. 2016) and, in some cases, foodborne diseases (Suzuki et al. 2015, Takeuchi et al. 2016). Kudoa Meglitsch, 1947 is one of the most studied myxozoan genera whose species infect a wide range of marine fishes from different geographic areas. Around 100 species of Kudoa have been described from wild fishes in different regions of the world (Eiras et al. 2014).

In the Eastern Atlantic, they have been reported as parasites of several small pelagic fish species such as Sardina pilchardus (Walbaum), Scomber scombrus Linnaeus, Trachurus trachurus (Linnaeus) and Trachurus picturatus (Bowdich) (Gaevskaya and Kovaleva 1985, Cruz et al. 2003, Levsen et al. 2008, Cruz et al. 2011). Spores of species of Kudoa have already been detected in the western 
Mediterranean, and more southwards alongside the African coast to the Gulf of Guinea in some large pelagic fish species, such as Thunnus obesus (Lowe) (Yurakhno and Gorchanok 2011). Wild fishes are not the only suitable intermediate hosts of Kudoa spp., because there are also reports of infections in various species from aquaculture. Atlantic salmon, Salmo salar Linnaeus, is one of the most affected species, with considerable commercial impact (Goater et al. 2014, Lafferty et al. 2015).

The life cycles of marine myxozoans are poorly known (Eszterbauer et al. 2015), with no data available for species of Kudoa. Generally, myxosporean life cycle has two different phases: an actinospore-phase taking place in invertebrate definitive hosts (annelids), where actinospores are produced, and a myxospore-phase that typically occurs in fishes, which are intermediate hosts. The actinospore is released into the water by the annelid and infects fish through direct contact with the gill epithelium or skin (Lom and Dyková 2006, Rangel et al. 2015, Rangel et al. 2016a,b, Atkinson et al. 2019).

Commercial fishes infected by Kudoa spp. can be rejected by consumers due to the presence of whitish or black hypertrophic muscular cells, repugnant appearance, or soft texture (post-mortem myoliquefaction) induced by these parasites, causing important commercial losses. However, the impact of some species of Kudoa on human health is more serious. Several cases of gastrointestinal problems, such as vomiting and diarrhea, were observed after ingestion of raw portions of fish infected with Kudoa septempunctata Matsukane, Sato, Tanaka, Kamata et Sugita-Konishi, 2010 (see Kawai et al. 2012, Iwashita et al. 2013). Since 2003 there has been an increase in raw fish consumption and consequently cases of food poisoning caused by Kudoa spp. (Kawai et al. 2012).

Myxozoans are generally specific parasites with a few exceptions, which include Kudoa thyrsites (Gilchrist, 1924) reported thus far from 40 fish species representing 18 families (Whipps and Kent 2006). This species is associated with post-mortem myoliquefaction in a wide range of host species. The analysis of genetic structure of $K$. thyrsites suggested a correlation of genetic samples with their geography and the existence of significant barriers in gene flow at a global scale that may lead to geographic isolation of regionally endemic populations or even emergence of cryptic species (Whipps and Kent 2006).

Scombrids are very important for fisheries in the Northeast Atlantic, with tunas and Atlantic mackerels in the ranking of the most landed species in the Portuguese mainland coast and the Madeira archipelago (INE 2018). However, to the best of our knowledge, studies on the occurrence of Kudoa in marine fishes have been carried out only in the Portuguese mainland coast in T. trachurus and S. pilchar$d u s$ (Cruz et al. 2003, 2011). There is also a report of the presence of Kudoa sp. in Scomber colias Gmelin from the Portuguese mainland coast (Alves 2016).

Considering gaps in the knowledge of the occurrence of Kudoa spp. in the Northeast Atlantic, the aim of this study was to evaluate the presence and infection levels of these myxozoans in marine fishes from the Portuguese mainland coast and, in particular, from the Madeira Archipelago. We focus mainly on scombrid fish because of their importance to local fisheries (Hermida and Delgado 2016), as well as on a variety of other fish species to provide a better picture of the occurrence of species of Kudoa in this region.

\section{MATERIALS AND METHODS}

\section{Sampling}

A total of 250 fishes from 19 species were sampled for detection of spores of Kudoa spp., between May 2016 and October 2017. The main focus of the study were scombrids from the Madeira Archipelago in the North Atlantic Ocean: 22 albacore Thunnus alalunga (Bonnaterre), 33 Atlantic chub mackerel Scomber colias, 30 bigeye tuna Thunnus obesus, and 30 skipjack tuna Katsuwonus pelamis (Linnaeus) (Table 1).

Furthermore, a mixed sample of different species of fishes were included in this study to carry out a comprehensive survey of Kudoa spp. in important commercial species from the Madeira Archipelago: three grey triggerfish Balistes capriscus Gmelin, one barred hogfish Bodianus scrofa (Valenciennes), five leafscale gulper shark Centrophorus squamosus (Bonaterre), three pink dentex Dentex gibbosus (Rafinesque), one sharktooth moray Gymnothorax maderensis (Johnson), one island grouper Mycteroperca fusca (Lowe), one black gemfish Nesiarchus nasutus Johnson, two forkbeard Phycis phycis (Linnaeus), one wreckfish Polyprion americanus (Bloch et Schneider), 16 greater amberjack Seriola dumerili (Risso), 30 longfin yellowtail Seriola rivoliana Valenciennes, eight blacktail comber Serranus atricauda Günther, two red scorpionfish Scorpaena scrofa Linnaeus, and one yellowmouth barracuda Sphyraena viridensis Cuvier. In addition, 30 Atlantic chub mackerel S. colias and 30 blue whiting Micromesistius poutassou (Risso) from the northern part of the Portuguese mainland coast (Matosinhos) were also examined. Total length (TL), fork length (FL) and weight (W) were determined, and muscle samples were collected from each fish.

\section{Parasitological examination}

The method used to detect spores of Kudoa spp. was the one proposed by Saraiva et al. (2017). One gram of frozen dorsal muscle collected just posterior to the head of each fish was used, except for specimens of S. colias and M. poutassou, from which one gram of frozen muscle from each region of the fish (anterior, middle and posterior) was used. The muscle was placed on a lip of a Petri dish, moistened with $5 \mathrm{ml}$ of phosphate buffered saline (PBS), macerated with a scalpel and squashed with the base of the Petri dish. The squashed muscle was initially observed under a stereomicroscope for detection of infected hypertrophic muscle cells. Afterwards, the liquid was squeezed out into a centrifuge tube, allowing the spore suspension to settle for 30 minutes. Three drops of liquid $(\sim 25 \mu \mathrm{l})$ were then pipetted from the bottom of the tube to a microscope slide and covered with a coverslip.

Slides were observed under a Differential Interference Contrast (DIC) microscope at $400 \times$ magnification. Detected kudoid spores were photographed with a camera integrated into the microscope and measured according to Burger and Adlard (2010). Spore width and thickness and polar capsules width and length were measured in spores in apical view and spore length was measured in spores in lateral view. 


\section{Data analysis}

Mean and standard deviation were calculated for host parameters (TL, FL, and W). Prevalence, mean intensity and mean abundance of spores were determined based on definitions proposed by Bush et al. (1997), except that the quantification was done not on the host but on a sample of host muscle obtained by the methodology described above.

Statistical analyses were carried out using IBM SPSS 25 statistics software (IBM 2017). Differences in parasite abundance among the three regions of $M$. poutassou and $S$. colias were compared using non-parametric tests for related samples. The Cochran test was used for occurrence comparisons and Friedman's analysis of variance by ranks for abundance comparisons. For all tests, statistical significance was accepted when $\mathrm{p}<0.05$.

\section{DNA extraction, PCR amplification and sequencing}

Total DNA was extracted from samples using a standard phenol-chloroform protocol, after an overnight digestion with proteinase $\mathrm{K}$ (50 $\mu \mathrm{g} \mathrm{ml}^{-1}$; Serva, Heidelberg, Germany), at $55^{\circ} \mathrm{C}$ (Holzer et al. 2004). DNA was resuspended in $50-100 \mu \mathrm{l}^{-1}$ of DNAse-free water and left to dissolve overnight at $4{ }^{\circ} \mathrm{C}$. PCRs were performed using an AccuPower ${ }^{\circledR}$ PCR PreMix (Bioneer,

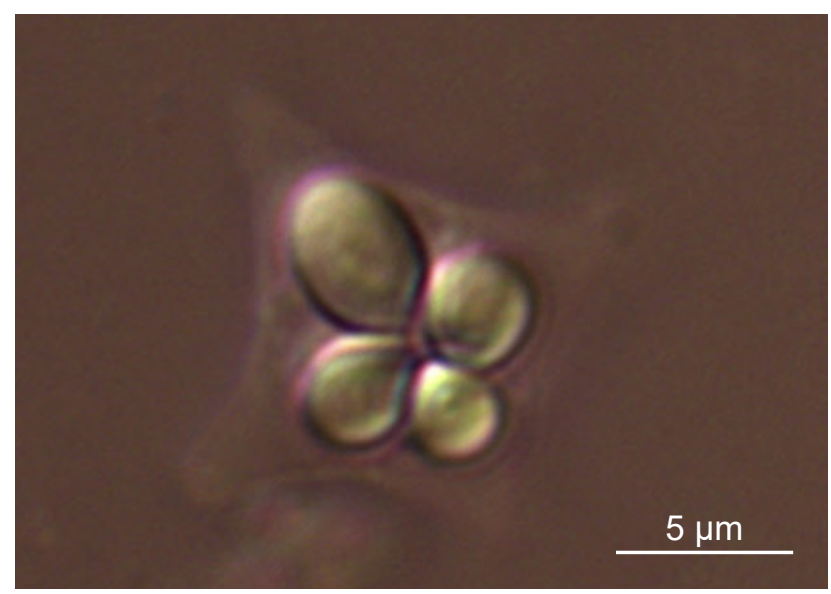

Fig. 1. Spore of Kudoa sp. from Thunnus obesus (Lowe) from Madeira Archipelago.

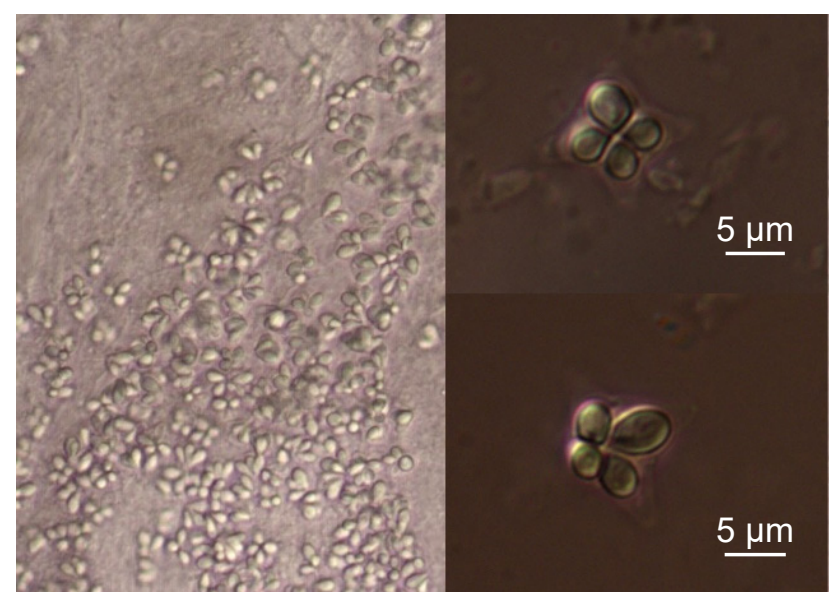

Fig. 2. Spore of Kudoa sp. from Scomber colias Gmelin from Portuguese mainland coast.
Daejeon, South Korea) with 25 pmol of each primer, $18 \mu 1$ of water and $1 \mu 1$ (approx. $100 \mathrm{ng}$ ) of extracted DNA.

Initially, we used a primer pair MyxospecF+18R (Whipps et al. 2003, Fiala 2006). This approach failed to give a positive PCR result for the sample from $M$. poutassou as well as for samples from S. colias from Madeira. Therefore, nested PCR was performed with initial primer pair $18 \mathrm{e}+18 \mathrm{~g}$ (Hillis and Dixon 1991) followed by PCR with specific Kudoa primer pair KUD1f + KUD2r (Hervio et al. 1997) or semispecific KUD1f + 18g.

Cycling parameters were set up as follows: initial PCR run: denaturation $95^{\circ} \mathrm{C}$ for $3 \mathrm{~min}$, followed by 30 cycles of $94^{\circ} \mathrm{C}$ for $1 \mathrm{~min}, 58^{\circ} \mathrm{C}$ for $1 \mathrm{~min} \mathrm{~s}, 72^{\circ} \mathrm{C}$ for $2 \mathrm{~min}$ and after cycles a terminal extension at $72^{\circ} \mathrm{C}$ for $10 \mathrm{~min}$; II run: denaturation $95^{\circ} \mathrm{C}$ for $3 \mathrm{~min}$, followed by 35 cycles of $94^{\circ} \mathrm{C}$ for $40 \mathrm{~s}, 55^{\circ} \mathrm{C}$ for $50 \mathrm{~s}$, $72^{\circ} \mathrm{C}$ for $1 \mathrm{~min} 40 \mathrm{~s}$ with terminal extension at $72^{\circ} \mathrm{C}$ for $10 \mathrm{~min}$. PCR products were purified using a Gel/PCR DNA Fragments Extraction Kit (Geneaid Biotech Ltd., New Taipei City, Taiwan) and sequenced directly (SeqMe, Dobříš, Czech Republic). Sequences were deposited in GenBank under the accession numbers MT991409 and MT991410.

\section{Phylogenetic analysis}

Based on an initial BLAST search of SSU rDNA, sequences from M. poutassou and $S$. colias showed a high match score with $K$. thyrsites. Therefore, we retrieved nucleotide sequences of $K$. thyrsites and its related species from GenBank and aligned them with the newly obtained sequence using MAFFT v7.450 algorithm (Katoh et al. 2013) implemented in Geneious v8.0.5 (Kearse et al. 2012) using the E-INS-i multiple alignment meth-

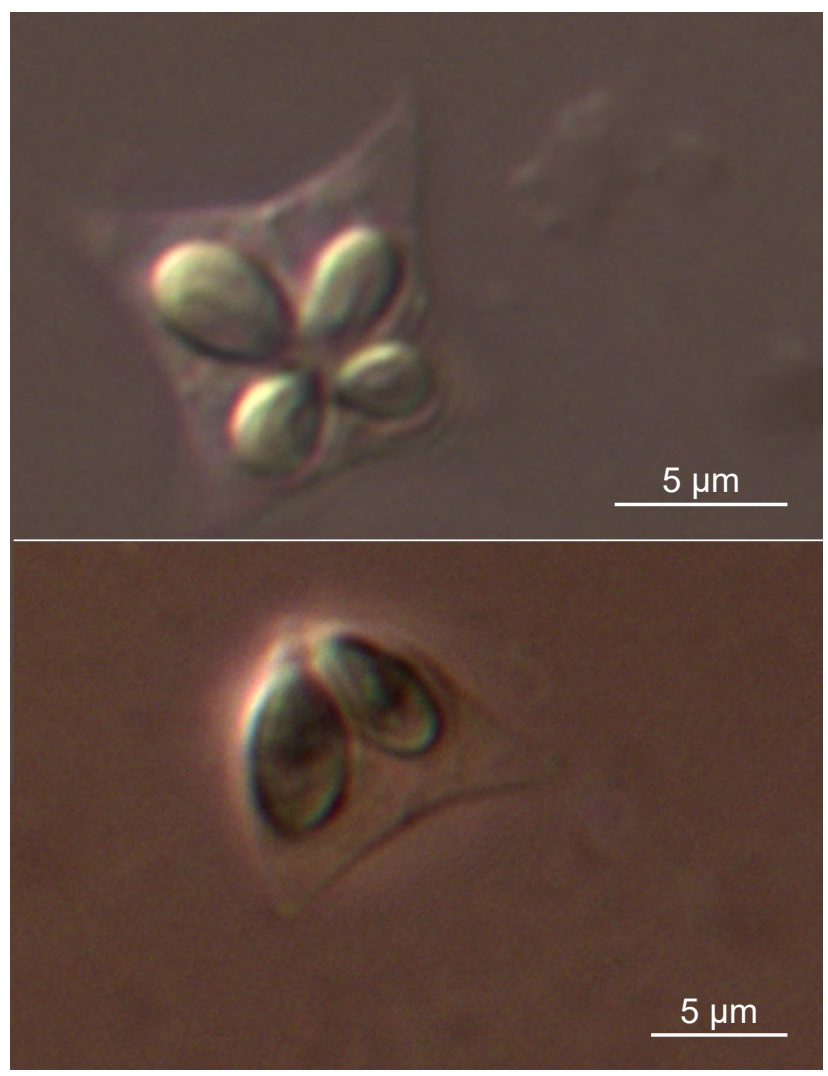

Fig. 3. Spore of Kudoa sp. from Micromesistius poutassou (Risso) from Portuguese mainland coast. 
od, with a gap opening penalty (-op) of 1.5 and gap extension penalty (-ep) of 0.123. Maximum likelihood (ML) analysis was performed in RAxML v7.0.3 (Stamatakis 2006) using the GTR $+\Gamma$ model of nucleotide substitution. Kudoa lateolabracis Yokoyama, Whipps, Kent, Mizuno et Kawakami, 2004 was set as an outgroup. Bootstraps were based on 1,000 replicates. The intraspecific differences were determined from proportional distances of SSU rDNA, which were calculated in Geneious (p-dist) from the dataset previously used for the phylogenetic analysis.

\section{RESULTS}

Taxonomic and biometric data of all 250 examined fishes are detailed in Table 1. From all examined specimens from the Madeira Archipelago, no hypertrophic muscle cells were evident macroscopically. Only a single spore of a species of Kudoa was found in one specimen of Thunnus obesus by light microscopy. The spore was stellate in apical view and had four pyriform capsules of unequal size (Fig. 1). We found 18 out of 30 Scomber colias and 24 out of 30 Micromesistius poutassou individuals positive for infection with species of Kudoa $(60 \%$ and $80 \%$ prevalence, respectively). In both cases, spores were observed in the muscle from all three sampled body regions (anterior, middle and posterior), and infection levels varied between them (Table 2). However, in S. colias, no significant differences were observed either in the occurrence or in the abundance (measured as the number of spores in the three drops of liquid examined) among the three regions. Likewise, no significant differences were detected in the occurrence of parasites in M. poutassou, but significant differences in abundance were detected among regions ( $\mathrm{p}=$ 0.040). Spores of Kudoa sp. found in S. colias (Fig. 2) and M. poutassou (Fig. 3) were stellate in apical view and had four pyriform polar capsules of three different sizes: one large, two intermediate and one small. Myxospore measurements from spores detected in T. obesus and M. poutassou are shown in Table 3.

Both SSU rDNA sequences of Kudoa from S. colias and M. poutassou were identical and revealed $100 \%$ identity with Kudoa thyrsites (AY078430) from its type species Thyrsites atun (Euphrasen) from the coast of South Africa as well as with $K$. thyrsites from Merluccius capensis Castelnau from the coast of South Africa (AY941819) and S. scombrus from Northern North Sea (EU154349) and the South coast of England, North Sea (AY542482). The comparison was done based on a 1,096 bp and 824 bp long sequence of Kudoa sp. from S. colias and M. poutassou, respectively. Phylogenetic analysis revealed four lineages of $K$. thyrsites genotypes (Fig. 4). Kudoa sp. from $S$. colias and $M$. poutassou clustered with sequences of $K$. thyrsites (AY078430, AY941819, EU154349, AY542482, AY542481) with 91\% bootstrap support (Fig. 4). Molecular screening of 33 specimens of $S$. colias from the Madeira Archipelago was negative for infection with Kudoa spp.

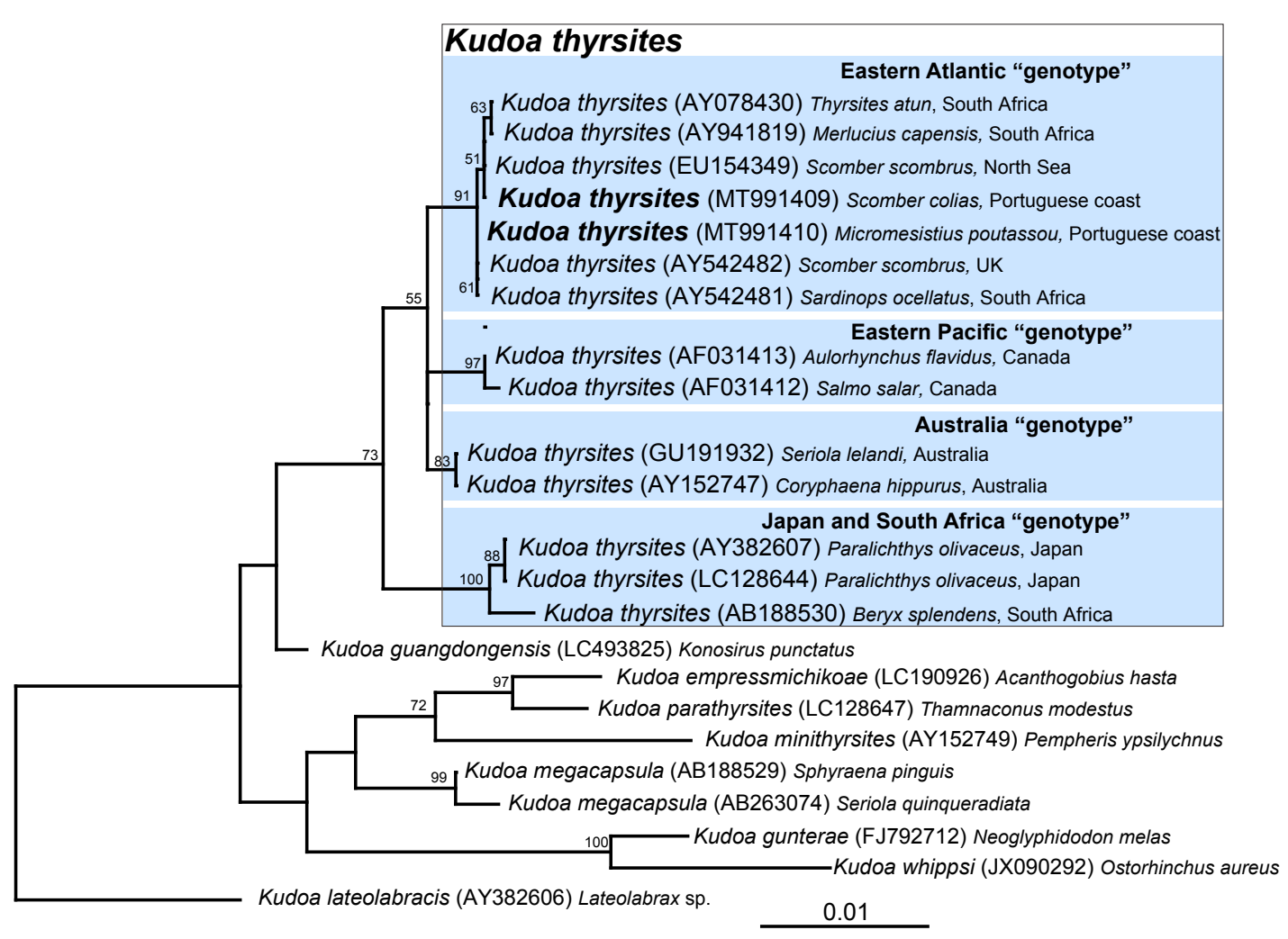

Fig. 4. Maximum likelihood tree of SSU rDNA sequences of Kudoa thyrsites (Gilchrist, 1924) and its closely related species. Newly identified sequences are in bold. Maximum likelihood bootstrap nodal supports are shown at every node. GenBank acc. numbers are given after the species names and scale is given under the tree. 
Table 1. Fish species examine from the Madeira archipelago and the Portuguese mainland coast, number of specimens (n) and their biological parameters: total length (TL), fork length (FL) and weight $(\mathrm{W})$. Values of measured biological parameters are listed as a mean \pm standard deviation.

\begin{tabular}{lcccc}
\hline Species & n & TL (cm) & FL (cm) & W (g) \\
\hline Madeira Archipelago & & & & \\
\hline Balistes capriscus & 3 & $48.5 \pm 1.6$ & $41.8 \pm 3.9$ & $1,822 \pm 346$ \\
Bodianus scrofa & 1 & 51.0 & N/A & 2362 \\
Centrophorus squamosus & 5 & $107.0 \pm 4.4$ & N/A & $6,205 \pm 918$ \\
Dentex gibbosus & 3 & $88.4 \pm 11.0$ & $79.4 \pm 9.7$ & $9,211 \pm 2749$ \\
Gymnothorax maderensis & 1 & 90.0 & $\mathrm{a}$ & 1589 \\
Katsuwonus pelamis & 30 & $53.6 \pm 3.3$ & $50.6 \pm 3.1$ & $2,869 \pm 642$ \\
Mycteroperca fusca & 1 & 69.0 & 65.7 & 4533 \\
Nesiarchus nasutus & 1 & 127.0 & N/A & 5385 \\
Phycis phycis & 2 & $51.9 \pm 3.0$ & N/A & $1,576 \pm 117$ \\
Polyprion americanus & 1 & 64.7 & N/A & 4565 \\
Scomber colias & 33 & $24.1 \pm 4.5$ & $21.9 \pm 4.0$ & $128 \pm 110$ \\
Scorpaena scrofa & 2 & $44.0 \pm 3.7$ & N/A & $1,655 \pm 208$ \\
Seriola dumerili & 16 & $110.5 \pm 33.7$ & $99.1 \pm 29.6$ & $17,505 \pm 9417$ \\
Seriola rivoliana & 30 & $52.2 \pm 13.6$ & $46.4 \pm 11.8$ & $2,344 \pm 3842$ \\
Serranus atricauda & 8 & $30.6 \pm 3.2$ & N/A & $385 \pm 178$ \\
Sphyraena viridensis & 1 & 44.0 & 38.4 & 313 \\
Thunnus alalunga & 22 & $95.1 \pm 4.7$ & $87.9 \pm 3.8$ & $14,992 \pm 2282$ \\
Thunnus obesus & 30 & $85.3 \pm 8.9$ & $77.6 \pm 9.5$ & $10,654 \pm 3399$ \\
\hline Portuguese Continental Coast & & \\
Micromesistius poutassou 30 & $19.4 \pm 1.0$ & $17.7 \pm 0.9$ & $41 \pm 9.6$ \\
Scomber colias & 30 & $28.4 \pm 3.1$ & $26.2 \pm 3.0$ & $178 \pm 64$ \\
\hline N/A - not available & & & & \\
& & &
\end{tabular}

\section{DISCUSSION}

Only around ten species of Kudoa have been described from the northeast Atlantic Ocean out of approximately 100 nominal species (Eiras et al. 2014). In the Portuguese mainland coast, their occurrence was reported in greater amberjack Seriola dumerili (Kudoa insolita Kovaleva, Shulman et Yakovlev, 1979), Atlantic horse mackerel Trachurus trachurus (Kudoa sp.) (Cruz et al. 2003) and European pilchard Sardina pilchardus (Kudoa sp. with morphology and morphometry consistent with Kudoa thyrsites) (Cruz et al. 2011). However, there are no studies on the occurrence of Kudoa spp. in the Madeira Archipelago. Our survey of 190 fishes of 18 different species from this archipelago seems to indicate the absence/very rare occurrence of parasites of the genus Kudoa in this region.

This is the first reference to the occurrence of the genus Kudoa in the blue whiting Micromesistius poutassou. Based on spore morphology and molecular analysis, this species was also identified as $K$. thyrsites, confirming the euryxenous host specificity of this parasite at the level of intermediate fish hosts. This Kudoa sp. as well as Kudoa sp. from Scomber colias from the Portuguese mainland coast were morphologically identical with $K$. thyrsites, which was confirmed by molecular analysis that showed $100 \%$ identity of both sequences with $K$. thyrsites from the type host. SSU rDNA sequences of our samples clustered with sequences of $K$. thyrsites from the eastern Atlantic genotype sensu Whipps and Kent (2006), which includes isolates from fish in the Eastern Atlantic.

Our phylogenetic analysis including the newly identified $K$. thyrsites from M. poutassou and S. colias from the Portuguese mainland coast supported the idea that the
Table 2. Infection levels of Kudoa Meglitsch, 1947 in three muscle regions of Atlantic chub mackerel, Scomber colias Gmelin $(\mathrm{n}=30)$ and blue whiting, Micromesistius poutassou (Risso) $(\mathrm{n}=30)$ from the Portuguese mainland coast. P (\%), CI - 95\% confidence interval, SD (range).

\begin{tabular}{lccc}
\hline $\begin{array}{l}\text { Muscle region } \\
\text { S. colias }\end{array}$ & $\begin{array}{c}\text { Prevalence (CI) } \\
\%\end{array}$ & $\begin{array}{c}\text { Mean intensity } \\
( \pm \text { SDD })\end{array}$ & $\begin{array}{c}\text { Mean abundance } \\
( \pm \text { SD })\end{array}$ \\
\hline Anterior & $50(33-70)$ & $\begin{array}{c}88 \pm 219 \\
(1-831)\end{array}$ & $\begin{array}{c}45 \pm 159 \\
(0-831)\end{array}$ \\
Middle & $43(27-63)$ & $\begin{array}{c}137 \pm 438 \\
(1-1650)\end{array}$ & $\begin{array}{c}597 \pm 301 \\
(0-1,650)\end{array}$ \\
& & $140 \pm 247(1-734)$ & $\begin{array}{c}47 \pm 153 \\
(0-734)\end{array}$ \\
Posterior & $33(17-50)$ & & \\
\hline M. poutassou & & & $18 \pm 35$ \\
Anterior & $60(43-77)$ & $(1-144)$ & $(0-144)$ \\
& & $41 \pm 63$ & $29 \pm 56$ \\
Middle & $70(53-87)$ & $(1-232)$ & $(0-232)$ \\
& & $63 \pm 94$ & $46 \pm 85$ \\
Posterior & $73(57-87)$ & $(1-306)$ & $(0-306)$ \\
\hline
\end{tabular}

phylogeny of $K$. thyrsites genotypes correlates with geographic distribution. The host range of $K$. thyrsites is thus broadened to include two economically important fishes, namely Atlantic chub mackerel and blue whiting.

A high prevalence $(60 \%)$ of $K$. thyrsites detected in $S$. colias from the mainland coast contrasts greatly with no detection of $K$. thyrsites in $S$. colias from the Madeira Archipelago. This divergence is heightened by the almost complete absence of any species of Kudoa in fishes from Madeira, which is in accordance with the study of Shukhgalter (2004) who reported Kudoa sp. in chub mackerel from Mauritania (a coastal zone) and its absence in specimens from the Azores, where environmental conditions are similar to those in Madeira, which lacks a continental shelf, and where the insular shelf is quite narrow. Results of the present study may also provide additional information about the stock structure of $S$. colias in the Northeastern Atlantic. The presence of $K$. thyrsites in Atlantic chub mackerel from the Portuguese mainland coast and no detection in fish from the Madeira archipelago suggests that the specimens observed may belong to two different populations.

To the best of our knowledge, no life cycle of any species of Kudoa has yet been described (Eszterbauer et al. 2015). However, the life cycle is likely similar to that of other genera of the Myxosporea, with the presence of two hosts, annelids (probably a marine polychaete) and fishes. In the Madeira Archipelago, the ocean depth increases steeply at a short distance from the coast; there is no continental shelf, and the insular shelf is quite narrow. In addition, oceanic waters in this region have low productivity (Hermida and Delgado 2016). These conditions may explain the reduced abundance of benthic organisms, and consequently, it is possible that the occurrence of annelids near the Madeiran coasts is very low, or even that the specific hosts of Kudoa spp. might not be present in this region.

Thunnus spp. have been reported as hosts of several species of parasites of the genus Kudoa in wild and cultured fishes from Japan (Zhang et al. 2010, Meng et al. 2011, 
Table 3. Measurements (W - width; T - thickness; L - length) of the spores detected in the muscle of Micromesistius poutassou (Risso) and Thunnus obesus (Lowe) in $\mu \mathrm{m}$.

\begin{tabular}{|c|c|c|c|c|c|c|c|c|c|c|c|}
\hline & \multirow{2}{*}{\multicolumn{3}{|c|}{ Spore }} & \multicolumn{4}{|c|}{ Apical view } & \multicolumn{4}{|c|}{ Side view } \\
\hline & & & & \multicolumn{2}{|c|}{$\begin{array}{l}\text { Large polar } \\
\text { capsule }\end{array}$} & \multicolumn{2}{|c|}{$\begin{array}{l}\text { Small polar } \\
\text { capsule }\end{array}$} & \multicolumn{2}{|c|}{$\begin{array}{l}\text { Large polar } \\
\text { capsule }\end{array}$} & \multicolumn{2}{|c|}{ Small polar capsule } \\
\hline & $\mathrm{W}$ & $\mathrm{T}$ & $\mathrm{L}$ & $\mathrm{L}$ & W & $\mathrm{L}$ & $\mathrm{W}$ & $\mathrm{L}$ & W & $\mathrm{L}$ & $\mathrm{W}$ \\
\hline \multicolumn{12}{|c|}{ M. poutoussou } \\
\hline Mean & 15.2 & 8.3 & 8.4 & 4.7 & 3.2 & 3.7 & 2.5 & 6.1 & 3.2 & 5.0 & 2.6 \\
\hline $\mathrm{Sd}$ & 0.90 & 0.67 & 0.53 & 0.48 & 0.25 & 0.51 & 0.30 & 0.61 & 0.30 & 0.41 & 0.23 \\
\hline Minimum & 14.0 & 7.5 & 7.4 & 3.6 & 2.5 & 3.1 & 1.3 & 5.3 & 2.5 & 4.0 & 2.4 \\
\hline Maximum & 17.8 & 10.8 & 9.0 & 6.3 & 3.6 & 5.9 & 3.0 & 6.9 & 3.7 & 5.6 & 3.1 \\
\hline $\mathrm{n}$ & 30 & 30 & 15 & 35 & 35 & 35 & 35 & 13 & 13 & 12 & 12 \\
\hline T. obesus & - & 7.4 & - & 4.9 & 2.7 & 3.0 & 2.5 & - & - & - & - \\
\hline $\mathrm{n}$ & & 1 & & 1 & 1 & 1 & 1 & & & & \\
\hline
\end{tabular}

Abe and Maehara 2013). Although Japan is also an archipelago, it has an extended continental shelf, which can provide the ideal environmental conditions for the occurrence of benthic annelids, allowing Kudoa spp. to complete their life cycle in their waters. This could explain the difference between the high infection rates by Kudoa spp. in fishes from Japan and the extremely low prevalence of Kudoa spp. in this study.

Furthermore, the presence of Kudoa sp. in T. obesus does not indicate that this parasite can complete its life cycle in Madeira, since bigeye tuna is a highly migratory species, and thus could have acquired the infection elsewhere. In the Eastern Atlantic, bigeye tuna could acquire the infection, for example, in the African continental shelf, where this parasite was previously reported by Henning et al. (2013).

The results of this study indicate that the occurrence of Kudoa spp. in Madeiran waters appears to be uncommon.
This seems to indicate that fishes from the Madeira Archipelago present a limited risk in terms of the danger of Kudoa food poisoning. In any case, European Union recommendations of the adequate preparation of fish products should be followed (EFSA 2010).

Acknowledgements. Some of the fishes observed in this study were acquired by the Regional Fisheries Directorate of Madeira (DRP), under the framework of the Programa Nacional de Recolha de Dados da Pesca (multiannual European Union programme for the collection, management and use of data in the fisheries and aquaculture sectors). M. Hermida was financially supported by a postdoctoral grant from ARDITI (project No. M142009-5369-FSE-000001). This study was partially supported by the Oceanic Observatory of Madeira Project (M1420-01-0145FEDER-000001-Observatório Oceânico da Madeira-OOM), by Fundação para a Ciência e Tecnologia (FCT), through the strategic projects UID/MAR/04292/2019 granted to MARE, the UID/ Multi/04423/2019 granted to CIIMAR and the Czech Science Foundation (project No. 19-28399X).

\section{REFERENCES}

Abe N., Maehara T. 2013: Molecular characterization of kudoid parasites (Myxozoa: Multivalvulida) from somatic muscles of Pacific bluefin (Thunnus orientalis) and yellowfin (T. albacores) tuna. Acta Parasitol. 58: 226-230.

Alves M.F. 2016: Survey of parasites of Atlantic chub mackerel (Scomber colias) with economic and public health impact. MSc thesis, University of Porto, Porto, 20 pp.

Atkinson S.D., Hallett S.L., Díaz-Morales D., Bartholomew J.L., DE Buron I. 2019: First myxozoan infection (Cnidaria: Myxosporea) in a marine polychaete from North America and erection of actinospore collective group Saccimyxon. J. Parasitol. 105: 252-262.

Burger M.A., Adlard R.D. 2010: Four new species of Kudoa Meglitsch, 1947 (Myxosporea: Multivalvulida) from Australia with recommendations for species descriptions in the Kudoidae. Parasitology 137: 793-814.

Bush A.O., Lafferty, K. D., Lotz J.M., Shostak A.W. 1997: Parasitology meets ecology on its own terms: Margolis et al. revisited. J. Parasitol. 83: 575-583.

Cruz C., Silva A., Saraiva A. 2011: Intensity of Kudoa sp. infection and alteration of muscle texture in Sardina pilchardus in Portugal. Bull. Eur. Assoc. Fish Pathol. 31: 205-210.

Cruz C., Vaz A., Saraiva A. 2003: Occurrence of Kudoa sp. (Myxozoa) in Trachurus trachurus (Osteichthyes) in Portugal. Parasite 10: 165-167.
Eiras J.C., Saraiva A., Cruz C. 2014: Synopsis of the species of Kudoa Meglitsch, 1947 (Myxozoa: Myxosporea: Multivalvulida). Syst. Parasitol. 87: 153-180.

EFSA Panel on Biological Hazards (BIOHAZ) 2010: Scientific opinion on risk assessment of parasites in fishery products. EFSA J. 8: 1543.

Eszterbauer E., Athinson S., Diamant A., Morris D., El-Matbouli M., Hartikainen H. 2015: Myxozoan life cycles: practical approaches and insights. In: B. Okamura, A. Gruhl and J. L. Bartholomew (Eds.), Myxozoan Evolution, Ecology and Development. Springer International Publishing, Cham, pp. 175-198.

FialA I. 2006: The phylogeny of Myxosporea (Myxozoa) based on small subunit ribosomal RNA gene analysis. Int. J. Parasitol. 36: 1521-1534.

Gaevskaya A.V., Kovaleva A.A. 1985: [The parasite fauna of the oceanic horse mackerel Trachurus picturatus picturatus and eco-geographical characteristics of its formation.] Ekologiya Morya 20: 80-84. (In Russian.)

Goater T.M., Goater C.P., Esch G.W. 2014: Myxozoa: the spore-forming cnidarians. In: J.W. Lewis (Ed.), Parasitism: the Diversity and Ecology of Animal Parasites. Cambridge University Press, Cambrige, pp. 96-110.

Henning S.S., Hoffman L.C., Manley M. 2013: A review of Kudoa-induced myoliquefaction of marine fish species in South Africa and other countries. S. Afr. J. Sci. 109: 1-5. 
Hermida M., Delgado J. 2016: High trophic level and low diversity: would Madeira benefit from fishing down? Mar. Policy 73: 130-137.

Hervio D.M.L., Kent M.L., Khattra J., Sakanari J., Yokoyama H., Devlin R.H. 1997: Taxonomy of Kudoa species (Myxosporea), using a small-subunit ribosomal DNA sequence. Can. J. Zool. 75: 2112-2119.

Hillis D.M., Dixon M.T. 1991: Ribosomal DNA - molecular evolution and phylogenetic inference. Q. Rev. Biol. 66: 411-453.

Holzer A.S., Sommerville C., Wootten R. 2004: Molecular relationships and phylogeny in a community of myxosporeans and actinosporeans based on their 18S rDNA sequences. Int. J. Parasitol. 34: 1099-1111.

IBM CoRP. Released 2017: IBM SPSS Statistics for Windows, Version 25.0. IBM Corporation, Armonk, NY. https://www.ibm. com/products/spss-statistics

INE I.P. 2018: Estatísticas da Pesca 2017. Instituto Nacional de Estatística. Lisboa, Portugal.

Iwashita Y., Kamijo Y., Nakahashi S., Shindo A., Yokoyama K., Yamamoto A., Omori Y., Ishikura K., Fujioka M., Hatada T., Takeda T., Maruyama K., Imai H. 2013: Food poisoning associated with Kudoa septempunctata. J. Emerg. Med. 44: 943-945.

Kasai A., Li Y.C., Mafie E., Sato H. 2016: Morphological and molecular genetic characterization of two Kudoa spp., K. musculoliquefaciens, and K. pleurogrammi n. sp. (Myxosporea: Multivalvulida), causing myoliquefaction of commercial marine fish. Parasitol. Res. 115: 1883-1892.

Katoh K., Standley D.M. 2013: MAFFT Multiple Sequence Alignment Software Version 7: Improvements in Performance and Usability. Mol. Biol. Evol. 30: 772-780.

Kawai T., Sekizuka T., Yahata Y., Kuroda M., Kumeda Y., Iijima Y., Kamata Y., Sugita-Konoshi Y., Ohnishi T. 2012: Identification of Kudoa septempunctata as the causative agent of novel food poisoning outbreaks in Japan by consumption of Paralichthys olivaceus in raw fish. Clin. Infect. Dis. 54: 10461052.

Kearse M., Moir R., Wilson A., Stones-Havas S., Cheung M., Sturrock S., Buxton S., Cooper A., Markowitz S., Duran C., Thierer T., Ashton B., Meinties P., Drummond A. 2012: Geneious Basic: an integrated and extendable desktop software platform for the organization and analysis of sequence data. Bioinformatics 28: 1647-1649.

Kristmundsson Á., Freeman M.A. 2014: Negative effects of $\mathrm{Ku}$ doa islandica n. sp. (Myxosporea: Kudoidae) on aquaculture and wild fisheries in Iceland. Int. J. Parasitol. 3: 135-146.

Lafferty K.D., Harvell C.D., Conrad J.M., Friedman C.S., Kent M.L., Kuris A.M., Powell E.N., Rondeau D., SaKSIDA S.M. 2015: Infectious diseases affect marine fisheries and aquaculture economics. Annu. Rev. Mar. Sci. 7: 471-496.

Levsen A., Jørgensen A., Mo T. A. 2008: Occurrence of postmortem myoliquefactive kudoosis in Atlantic mackerel, Scomber scombrus L., from the North Sea. J. Fish Dis. 31: 601-611.

Loм J., DyкоvÁ I. 2006: Myxozoan genera: definition and notes on taxonomy, life-cycle terminology and pathogenic species. Folia Parasitol. 53: 1-36.

Meng F., Yokoyama H., Shirakashi S., Grabne D., Ogawa K., Ishimaru K., Sawada K., Murata O. 2011: Kudoa prunusi n. sp. (Myxozoa: Multivalvulida) from the brain of Pacific bluefin tuna Thunnus orientalis (Temminck \& Schlegel, 1844) cultured in Japan. Parasitol. Int. 60: 90-96.

Rangel L.F., Castro R., Rocha S., Cech G., Casal G., Azevedo C., Székely C., Cavaleiro F., Santos M.J. 2016a: Description of new types of sphaeractinomyxon actinospores (Myxozoa: Myxosporea) from marine tubificid oligochaetes, with a discussion on the validity of the tetraspora and the endocapsa as actinospore collective group names. Parasitol. Res. 115: 2341-2351.

Rangel L.F., Castro R., Rocha S., Severino R., Casal G., Azevedo C., Cavaleiro F., Santos M.J. 2016b: Tetractinomyxon stages genetically consistent with Sphaerospora dicentrarchi (Myxozoa: Sphaerosporidae) found in Capitella sp. (Polychaeta: Capitellidae) suggest potential role of marine polychaetes in parasite's life cycle. Parasitology 143: 1067-1073.

Rangel L.F., Rocha S., Castro R., Severino R., Casal G., Azevedo C., Cavaleiro F., Santos M.J. 2015: The life cycle of Ortholinea auratae (Myxozoa: Ortholineidae) involves an actinospore of the triactinomyxon morphotype infecting a marine oligochaete. Parasitol. Res. 114: 2671-2678.

Saraiva A., Alves M., Eiras J.C., Cruz C. 2017: Comparison of two methods for detection of Kudoa spores. Bull. Eur. Assoc. Fish Pathol. 37: 213-216.

ShukHGalter O.A. 2004: [The parasite fauna of the chub mackerel (Scombridae: Scomber japonicus Houttuyn, 1782) in the central-eastern Atlantic (Atlantic coast of the Northern Africa and the Azores Archipelago banks).] Parazitologiya 38: 160-170. (In Russian.)

Stamatakis A. 2006. RAxML-VI-HPC: maximum likelihood-based phylogenetic analyses with thousands of taxa and mixed models. Bioinformatics 22: 2688-2690.

Suzuki J., Murata R., Yokoyama H., Sadamasu K., Kai A. 2015: Detection rate of diarrhea-causing Kudoa hexapunctata in Pacific bluefin tuna Thunnus orientalis from Japanese waters. Int. J. Food Microbiol. 194: 1-6.

Takeuchi F., Ogasawara Y., Kato K., Sekizuka T., Nozak T., Sugita-Konishi Y., Ohnishi T., Kuroda M. 2016: Genetic variants of Kudoa septempunctata (Myxozoa: Multivalvulida), a flounder parasite causing foodborne disease. J. Fish Dis. 39: 667-672.

Whipps C.M., Adlard R.D., Bryant M.S., Lester R.J.G., Findlay V., Kent M.L. 2003: First report of three Kudoa species from eastern Australia: Kudoa thyrsites from mahi mahi (Coryphaena hippurus), Kudoa amamiensis and Kudoa minithyrsites n. sp. from sweeper (Pempheris ypsilychnus). J. Euk. Microbiol. 50: 215-219.

Whipps C.M., Diggles B.K. 2006: Kudoa alliaria in flesh of Argentinian hoki Macruronus magellanicus (Gadiformes; Merlucciidae). Dis. Aquat. Org. 69: 259-263.

Whipps C.M., Kent M.L. 2006: Phylogeography of the cosmopolitan marine parasite Kudoa thyrsites (Myxozoa: Myxosporea). J. Eukar. Microbiol. 53: 364-373.

Yurakhno V.M., Gorchanok N.V. 2011: [Myxosporidium $\mathrm{Ku}$ doa nova (Myxosporea: Kudoidae) - parasite of fish in the Black and Azov Seas.] Morskoy Ekol. Zh. 10: 68-77. (In Russian.)

Zhang J., Meng F., Yokoyama H., Miyahara J., Takami I., OGAwA K. 2010: Myxosporean and microsporidian infections in cultured Pacific bluefin tuna Thunnus orientalis in Japan. Fisheries Sci. 76: 981-990.

Cite this article as: Cavaleiro B., Serrão J., Nogueira S., Ribeiro L., Hermida M., Cruz C., Lisnerová M., Fiala I., Saraiva A. 2021: Survey of Kudoa spp. (Myxozoa, Cnidaria) in fishes from Madeira Archipelago and the Portuguese mainland coast: detection of Kudoa thyrsites in new hosts Scomber colias and Micromesistius poutassou. Folia Parasitol. 68: 003. 